\title{
OPTIMALISASI PEMBELAJARAN BAHASA INDONESIA MENGGUNAKAN MEDIA PEMBELAJARAN BERBASIS APLIKASI NEARPOD
}

\author{
Raudhatul Aslami \\ Program Studi Pendidikan Bahasa dan Sastra Indonesia, UIN Syarif Hidayatullah Jakarta \\ raudhatul.ami@gmail.com
}

\begin{abstract}
This study aims to discuss the optimization of Indonesian language learning using the Nearpod application as an ICT-based learning medium. The research method used is descriptive qualitative method. Data obtained based on observations, field notes (research), written interviews conducted online. The subjects of this study were ten students at the Junior High School and Senior High School levels. Meanwhile, the object of this research is the use of the Nearpod application in optimizing Indonesian language learning related to biographical material. The source of the data studied was through a learning process carried out online or online with the research subjects using the nearpod application. Based on the results and discussion in this study, the Nearpod application can be used for Indonesian language learning media because it can create interactive learning through innovative and educational features.
\end{abstract}

Keyword: Nearpod application, Indonesian language, learning media

\begin{abstract}
ABSTRAK
Penelitian ini bertujuan untuk membahas terkait optimalisasi pembalajaran bahasa Indonesia dengan menggunakan aplikasi Nearpod sebagai media pembelajaran berbasis ICT. Metode penelitian yang digunakan ialah metode deskriptif kualitatif. Data diperoleh berdasarkan hasil pengamatan, catatan (penelitian) lapangan, dan wawancara tertulis yang dilakukan secara daring. Subjek penelitian ini adalah sepuluh siswa tingkat Sekolah Mengah Pertama dan Sekolah Menengah Atas. Sementara, objek penelitian ini adalah penggunaan aplikasi Nearpod dalam mengoptimalkan pembelajaran bahasa Indonesia terkait materi teks biografi. Sumber data penelitian ini didapatkan melalui proses pembelajaran yang dilakukan secara daring atau online bersama subjek penlitian menggunakan aplikasi nearpod. Berdasarkan hasil dan pembahasan dalam penelitian ini, aplikasi Nearpod dapat dimanfaatkan untuk media pembelajaran bahasa Indoensia karena dapat menciptakan pembelajaran yang interaktif melalui fitur-fitur yang inovatif dan edukatif.
\end{abstract}

Kata Kunci: Aplikasi Nearpod, Bahasa Indonesia, Media pembelajaran

How to Cite: Ami, R. A. (2021). OPTIMALISASI PEMBELAJARAN BAHASA INDONESIA MENGGUNAKAN MEDIA PEMBELAJARAN BERBASIS APLIKASI NEARPOD. Bahtera Indonesia; Jurnal Penelitian Bahasa Dan Sastra Indonesia , 6(2), 135148. https://doi.org/10.31943/bi.v6i2.105

DOI: https://doi.org/10.31943/bi.v6i2.105

Program Studi Pendidikan Bahasa dan Sastra Indonesia 


\section{PENDAHULUAN}

Bahasa Indonesia sebagai bahasa persatuan bangsa Indonesia telah menjadi salah satu materi pelajaran wajib satuan pendidikan di Indonesia. Bahasa Indonesia dipelajari mulai dari Sekolah Dasar (SD), Sekolah Menengah Pertama (SMP), Sekolah Menengah Atas (SMA), hingga tingkat perguruan tinggi. Pembelajaran bahasa Indonesia mencakup keterampilan menyimak, berbicara, membaca, dan menulis, membutuhkan proses pembelajaran yang efektif, inovatif, kreatif, dan tidak monoton, sehingga materi pelajaran bisa dicerna dengan baik oleh para peserta didik.

\section{Pandemi Covid-19 (Corona Virus} Disease) sangat memberi dampak kepada pendidikan di Indonesia. Untuk mengurangi dan meredam penyebaran virus corona, pemerintah Indonesia memberi kebijakan dan aturan untuk belajar dari rumah. Sebagaimana tercantum pada Surat Edaran Menteri Pendidikan dan Kebudayaan Republik Indonesia Nomor 4 Tahun 2020 Tentang Pelaksanaan Kebijakan Pendidikan dalam Masa Darurat Penyebaran Coronavirus Disease (Covid-19). Guru dan peserta didik merupakan elemen penting dalam proses pembelajaran. Hubungan keduanya dalam pembelajaran semestinya berjalan dengan komunikatif dan interaktif sehingga tujuan pembelajaran tercapai dengan baik. Namun dalam pembelajaran jarak jauh (pjj) interaksi guru dan siswa terhambat, sehingga pelajaran kurang optimal. Hal ini menunjukkan adanya kesulitan belajar, salah satu faktor eksternal kesulitan belajar meliputi metode pembelajaran, media pembelajaran dan sumber belajar $(2013,: 5)$. Salah satu solusi untuk mengatasi masalah ini adalah diperlukan jembatan penyampaian pembelajaran, dalam hal ini disebut media pembelajaran, yang tepat agar guru dan siswa dapat optimal melakukan pembelajaran.

Sanaky dalam Suryani dkk menyebutkan, pembelajaran ialah proses komunikasi antara pembelajar, pengajar, dan bahan ajar (Suryani, 2018: 5). Media diambil dari bahasa Latin medius yang secara etimologi memiliki arti tengah, pengantar, dan perantara. Media dalam pembelajaran diartikan sebagai sesuatu untuk menyalurkan pesan dan pelajaran kepada siswa dalam proses pembelajaran. Sementara menurut Assosiation of Education and Communication Technology (AECT), media adalah segala bentuk saluran yang digunakan untuk menyalurkan pesan atau informasi (Angkowo dan Kosasih, 2007: 10). Pemilihan media perlu mempertimbangkan ketiga hal berikut: (1) Tujuan yang jelas dalam memilih media; (2) mengenal sifat dan ciri-ciri dari media yang akan digunakan ; (3) membandingkan dengan media pembelajaran yang lain untuk melihat ketepatan dengan tujuan pemilihan 
media (Angkowo dn Kosasih, 2007: 11). Salah satu jenis media pembelajaran ialah media berbasis ICT. Adapun media pembelajaran ICT (Information and Communication Technology) adalah alat bantu dalam prosses pembelajaran, baik di luar kelas maupun di dalam kelas. Perangkat ICT antara lain telepon seluler (handphone), komputer/laptop, LCD dan internet (Hamdanah dan Hasanuddin, 2019: 2) .

Pemanfaatan media pembelajaran berbasis Information Communication Technology (ICT) atau Teknologi Informasi dan Komunikasi (TIK) akan sangat mendukung proses pembelajaran dalam situasi dan kondisi seperti ini. Berhubung dengan hal tersebut, penggunaan teknologi, telepon seluler, dan internet, semakin ramai digandrungi masyarakat Indonesia. Berdasarkan data Statistik Telekomunikasi Indonesia tahun 2018, terjadi peningkatan penggunaan internet dalam indikator TIK sebesar 66,22 \%. Terhitung sejak 2014-2018, meningkatnya penggunaan internet penduduk ini dari presentase 17, $14 \%$ pada tahun 2014 dan mencapai 39,90\% di tahun 2018 yang dipengaruhi oleh berkembangnya penggunaan telepon seluler. (Sub Direktorat Statistik Komunikasi dan Teknologi Informasi, 2018: 20).

Melalui uraian data statistik tersebut, pemanfaatan media berbasis ICT agaknya dapat dioptimalkan untuk pembelajaran khususnya pembelajaran bahasa Indonesia. Berdasarkan data Kemkominfo, lokasi penggunaan internet oleh individu dengan persentase paling tinggi adalah Dimana saja melalui handphone sebesar $66,3 \%$ dan peringkat kedua tertinggi lokasi untuk menggunakan internet adalah di rumah $(50,2 \%)$. Oleh karena itu, untuk mewujudkan pembelajaran yang efektif, media pembelajaran ICT dapat memanfaatkan telepon seluler dan aplikasi pendukung pembelajaran, sehingga proses pembelajaran tak terbatas ruang dan waktu. Nearpod, misalnya, merupakan aplikasi pendukung pembelajaran yang dapat digunakan untuk mengoptimalkan pembelajaran, salah satunya bahasa Indonesia. Nearpod merupakan salah satu perangkat lunak (software) aplikasi pendukung pembelajaran. Aplikasi Nearpod memiliki banyak fitur menarik yang dapat digunakan untuk menunjang pembelajaran yang interaktif dan dapat di akses gratis oleh para siswa dan guru dari seluruh penjuru tak terbatas ruang dan waktu. Kendati demikian, aplikasi Nearpod belum banyak diketahui dan digunakan oleh khalayak umum, khususnya pemeran pendidikan.

Beberapa penelitian sebelumnya telah menyarankan aplikasi pendukung pembelajaran daring seperti Google Classroom, Lectora, Edmodo, dan aplikasi pendukung pembelajaran lainnya. Namun masih sedikit kali yang membahas mengenai 
aplikasi Nearpod dan pemanfaatannya dalam pembelajaran. Dengan demikian, pada kesempatan ini, peneliti berfokus kepada optimalisasi pembelajaran bahasa Indonesia dengan menggunakan aplikasi Nearpod sebagai media pembelajaran. Mengacu pada latar belakang permasalahan di atas, maka penelitian ini bertujuan untuk mendeskripsikan penggunaan aplikasi Nearpod untuk mengoptimalkan pembelajaran bahasa Indonesia.

\section{METODE}

Metode yang digunakan dalam penelitian ini adalah metode deskriptif kualitatif. Melalui metode ini, peneliti akan menjelaskan secara deskriptif tentang pengoptimalan pembelajaran bahasa Indonesia dengan menggunakan aplikasi Nearpod. Data diperoleh berdasarkan hasil pengamatan, catatan (penelitian) lapangan, dan wawancara tertulis yang dilakukan secara daring. Subjek penelitian ini adalah sepuluh siswa tingkat Sekolah Mengah Pertama dan Sekolah Menengah Atas. Sementara, objek penelitian ini adalah penggunaan aplikasi Nearpod dalam mengoptimalkan pembelajaran bahasa Indonesia terkait materi teks biografi. Sumber data penelitian ini didapatkan melalui proses pembelajaran yang dilakukan secara daring atau online bersama subjek penlitian menggunakan aplikasi nearpod. Adapun wujud data yang didapatkan diantaranya hasil pengamatan berupa hasil belajar siswa meliputi keaktifan, ketepatan dan kecepatan menjawab soal serta kuis yang diberikan peneliti, dan hasil wawancara tertulis yang juga dilakukan di dalam aplikasi Nearpod.

Menurut Sugiyono, pengumpulan data dalam metode penelitian kualitatif didapatkan secara apa adanya. Sementara, teknik pengumpulan data dilakukan dengan tiga cara yaitu observasi berperan serta (participant observaction), wawancara mendalam (in depth interview), dan dokumentasi (Sugiono, 2017). Penelitian ini menggunakan observasi dan wawancara tertulis yang dilakukan secara daring dan dokumentasi proses pembeljaran dalam pengumpulan data. Berpijak pada metode penelitian deskriptif kualitatif, maka peneliti menggunakan tiga tahap analisis, yaitu reduksi data, penyajian data, dan penarikan kesimpulan.

\section{HASIL DAN PEMBAHASAN}

\section{A. Pembelajaran Bahasa Indonesia}

Pada dasarnya, belajar bahasa dapat disebut belajar komunikasi. Sementara, pembelajaran bahasa bertujuan untuk membuat kecakapan para peserta didik dalam berkomunikasi, baik bahasa tulis ataupun bahasa lisan meningkat. Sesuai dengan kurikulum 2013, pembelajarn bahasa, khususnya bahasa Indonesia 
mengacu pada empat kecakapan, yaitu menyimak, mendengarkan, berbicara, dan membaca. Tujuan pembelajaran bahasa ialah mampu berkomunikasi dalam berbagai keadaan. Adapun kecakapan yang ditingkatkan antara lain daya tangkap makna, peran, daya tafsir, menilai, dan mengekspresikan diri dengan bahasa (Hanna, 2014: 52). Saksomo dalam Hanna (2014: 53) menyebutkan ada 12 teknik yang dapat digunakan dalam pembelajaran bahasa Indonesia yaitu ceramah, tanya jawab, diskusi, pemberian tugas dan resitasi, demonstrasi dan eksperimen, meramu pendapat, mengajar di laboratorium, induktif, inkuiri dan diskoveri, peragaan, dramatisasi, dan ostensif, simulasi, main peran, dan sosio drama, karya wisata dan bermain-main, dan yang terakhir ialah teknik elektik dan campuran.

Pembelajaran jarak jauh berarti proses pembelajaran yang biasanya dilakukan tatap muka di kelas, harus dialihkan ke dalam pembelajaran secara dalam jaringan (daring/online). Berdasarkan hasil wawancara kepada siswa SMP dan SMA di empat sekolah berbeda, di daerah kab. Bogor dan Depok, para siswa mengalami kesulitan dalam memahami materi bahasa Indonesia pada pjj ini. Pada penelitian ini, kesulitan didasarkan kepada faktor eksternal, yaitu situasi dan proses pembelajaran yang kurang interaktif dan tidak memberikan kesempatan siswa untuk siswa aktif, media pembelajaran yang tidak disiapkan dengan baik oleh tenaga pengajar, dan situasi rumah siswa yang kurang kondusif. Menurut para subjek penelitian, sebagian guru hanya mengalihkan pembelajaran bahasa Indonesia dengan pemberian tugas. Hal tersebut juga membuat para siswa menjadi jenuh, bosan, dan tidak memahami materi.

\section{B. Aplikasi Nearpod: Alternatif Media} Pembelajaran Interaktif

Nearpod adalah perangkat lunak yang dapat diakses mengggunakan internet dan juga bisa diunduh melalui play store pendukung di telepon seluler dan perangkat teknologi lainnya. Nearpod merupakan program kelas maya yang menawarkan pengalaman pembelajaran interaktif antara guru dengan siswa secara daring. Terdapat tiga peran yang tersedia untuk mengakses pembelajaran melalui Nearpod, yaitu murid (students), Guru (Teachers), dan pengelola (Administrators). Untuk proses pembelajaran yang perlu diakses hanyalah murid, dan guru saja. 
Ofneorpod

You'll wonder how you taught without it

Engaging media and formative assessments to make every lesson interactive.

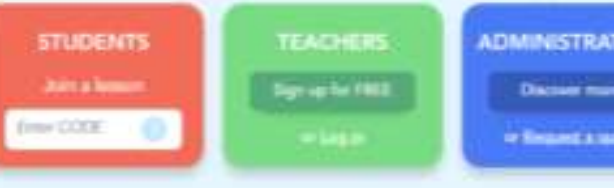

Para siswa tidak perlu membuat akun atau merancang pembelajaran layaknya guru. Untuk mengkses pembelajaran, murid hanya perlu mendapatkan kode kelas atau link yang dikirimkan oleh gurunya, untuk selanjutnya melakukan pembelajaran daring secara bersama-sama.

Seorang guru memiliki langkah akses yang berbeda dengan murid. Langkah pertama yang harus dilakukan oleh guru adalah mendaftarkan akun terlebih dahulu dengan memilih sign up, atau memilih $\log$ in jika sudah pernah mendaftar dan memiliki akun.

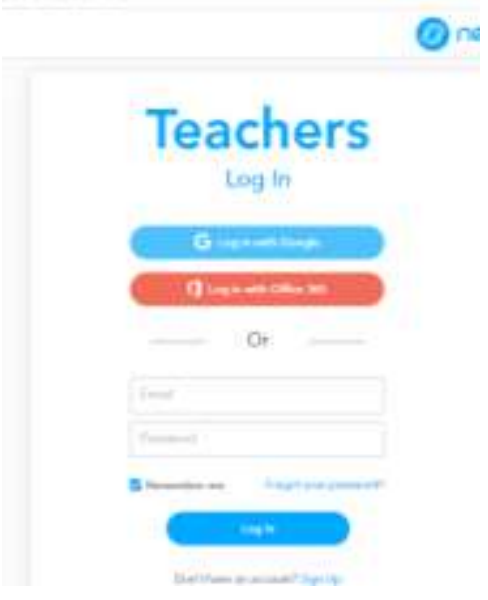

Aplikasi Nearpod ini telah terhubung dengan google dan office. Oleh karena itu, seorang guru yang ingin mendaftar atau masuk ke dalam Nearpod dapat menggunakan akun email gooogle atau office yang telah dimiliki sebelumnya. Jika belum memiliki kedua akun tersebut, seorang guru dapat membuat email baru dengan menuliskan di kolom email dan password yang telah tersedia.

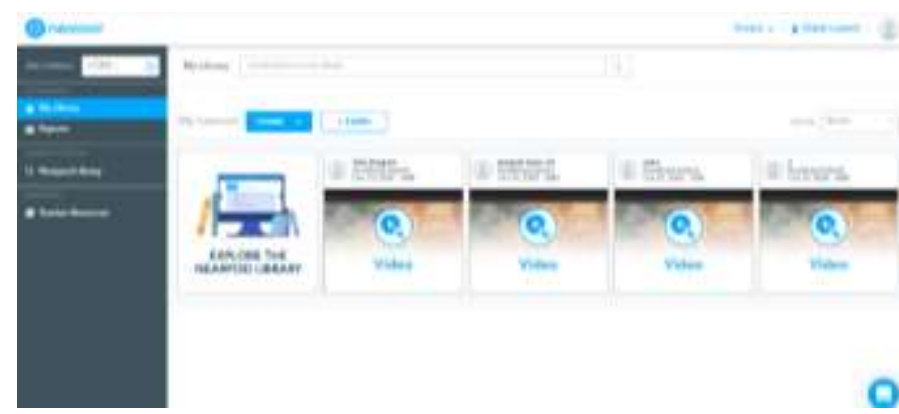

Setelah berhasil mendaftar dan memilih akun, akan muncul tampilan layar seperti gambar di atas. Tampilan tersebut merupakan laman akun Nearpod yang bisa diakses oleh guru. Melalui laman tersebut, guru dapat membuat kelas dan rancangan pembelajarannya atau modul kelas menggunakan fitur yang ada dalam Nearpod memilih create. Pada bagian create, seorang guru dapat memilih menggunakan lessons, videos, atau google slide. Pada kesempatan ini peneliti akan membatasi pennggunaan Nearpod dengan membuat rancangan pembelajaran mandiri melalui lessons. 

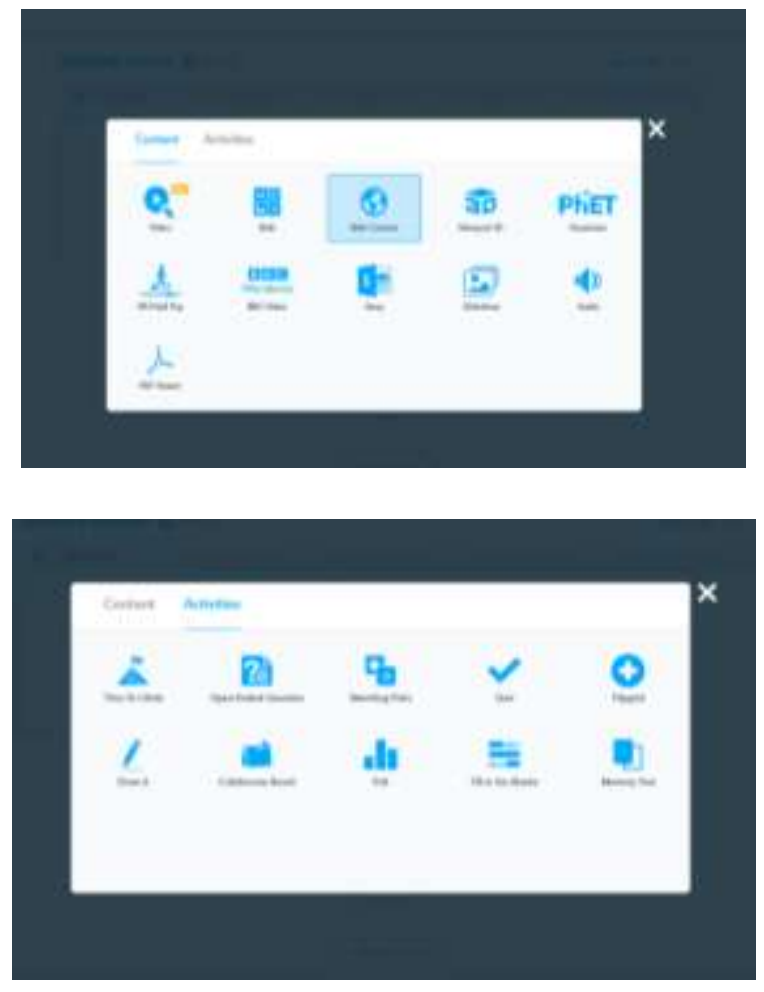

Sebagai media pembelajaran, guru dapat mengoptimalkan pembelajaran dengan merancang presentasi dengan memakai fitur teks, video, gambar, serta kuis-kuis yang terdapat dalam Nearpod. Nearpod memiliki banyak fitur-fitur menarik yang dapat dimanfaatkan untuk pembelajaran. Pada setiap salindia yang akan dibuat, guru dapat memilih fitur content atau activities yang disesuaikan dengan materi dan tujuan pembelajaran. Fitur content memiliki berbagai konten yang dapat digunakan diantaranya yaitu Video, Slide, Web Content, Nearpod 3D, Phet Simulation, VR Field Trip, BBC Video, Sway, Slideshow, Audio, atau PDF Viewer. Sementara untuk fitur activities meliputi aktivitas permainan edukasi yang dapat dimanfaatkan untuk mengetes, mengukur, dan melihat kemampuan siswa, atau dijadikan strategi untuk evaluasi pembelajaran yang telah dilakukan. Aktivitas tersebut antara lain, Time to Climb, Open Ended Question, Matching Pairs, Quiz, Flipgrid, Draw It, Collaborate Board, Poll, Fill in The Blanks, dan Memory Test.
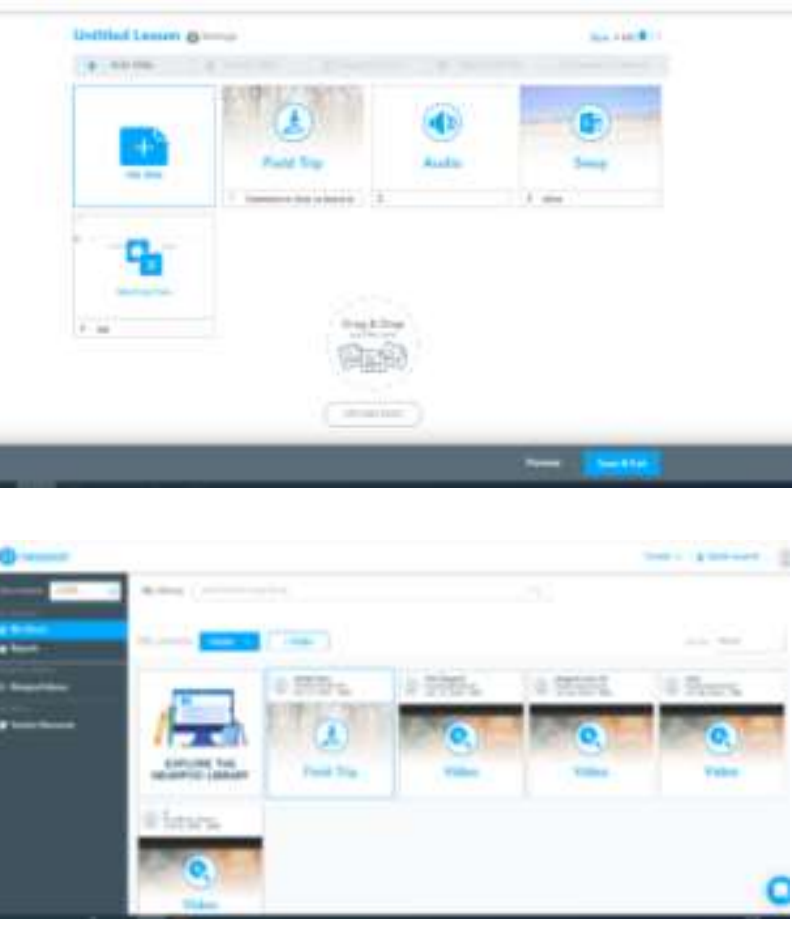

Salindia-salindia yang telah dibuat akan tersusun seperti tampilan layar pada gambar di atas. Penyusunan tersebut bisa diubah-ubah oleh guru dengan kesesuaian yang diinginkan, dan setiap salindia bisa diedit apabila ada yang ingin ditambahi, dikurangi, atau diperbaiki. Jika pembuatan modul atau materi pembelajaran telah selesai, guru dapat memilih tombol save \& exit untuk menyimpan dan kembali ke laman akun pribadi. Moodul dan materi- 
materi pembelajaran yang telah dibuat akan tersimpan di my library atau perpustakaan pribadi akun guru.

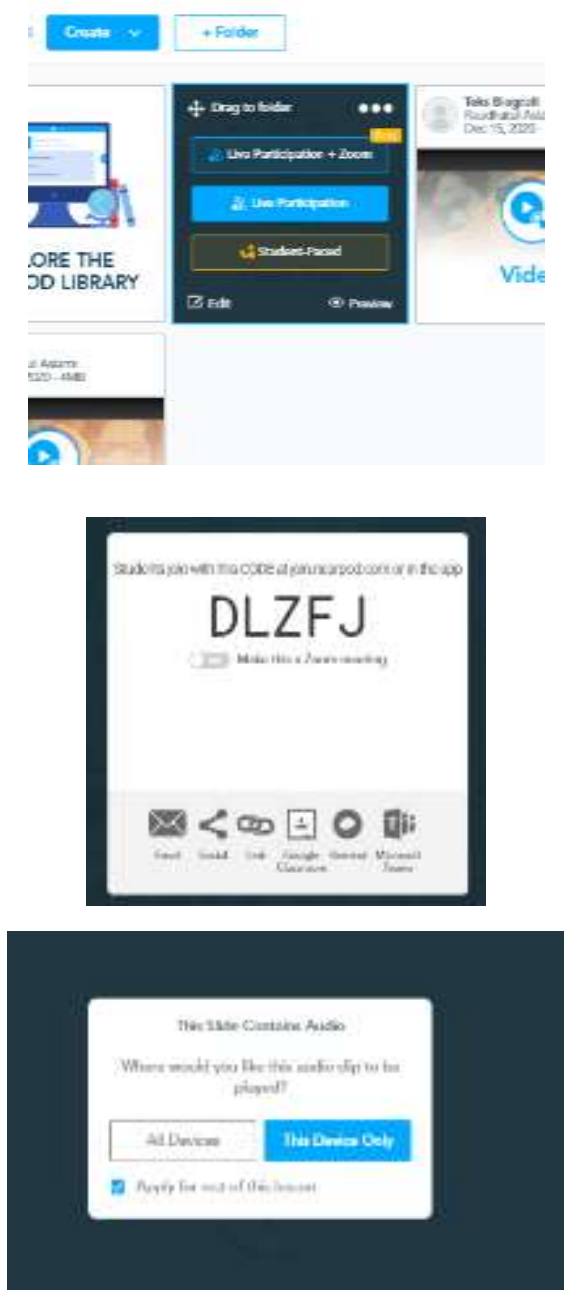

Untuk melakukan pembelajaran dengan para siswa, Nearpod menyediakan tiga pintu akses, yaitu Live Participation + Zoom, Live Participation, dan Student Paced. Setelah memilih pintu pembelajaran yang ingin dipakai, guru akan mendapatkan kode kelas untuk dibagikan kepada para siswa agar dapat bergabung dalam pembelajaran tersebut. Selanjutnya, guru dapat memilih All Devices agar seluruh partisipan yang tergabung dalam kode kelas dapat mengakses dan melihat pembelajaran. Setelah itu, pembelajaran akan dikelola oleh guru dan siswa akan berperan aktif tergantung dengan kekreativitas guru dalam merancang konten dan aktivitas belajar.

\section{Penggunaan Aplikasi Nearpod dalam Pembelajaran Bahasa Indonesia}

Penelitian ini menggunakan teks biografi sebagai materi pembelajaran bahasa Indonesia yang akan dipelajari oleh para subjek penelitian. Biografi dalam Kamus Besar Bahasa Indonesia (KBBI) berarti riwayat hidup (seseorang) yang ditulis oleh orang llain. Teks biografi juga meliputi struktur teks yang terdiri dari orientasi, rangkaian peristiwa (kejadian penting), dan reorientasi. Peneliti merancang pembelajarn secara mandiri menggunakan lessons dalam aplikasi Nearpod. Pada setip salindia, peneliti memanfaatkan elemen-elemen yang ada di fitur konten dan aktivitas dalam aplikasi Nearpod.

Adapun konten dan aktivitas yang digunakan dalam pembelajaran tek biografi ini yaitu Video, Slide, Slide Show, Web Content, Matching Pairs, Open Ended Question, Time To Climb, Fill In the Blank, dan Poll. Konten video digunakan satu kali pada awal pembelajaran, Slide 
digunakan sebanyak 6 kali untuk penjelasan materi, Slide Show untuk menampilkn power point yang telah dibuat peneliti 1 kali, Web Content 2 kali untuk menyajikan teks biografi, Matching Pairs untuk latihan menentukan struktur teks biografi, dan untuk menilai, mengamati pemahaman, dan mensurvei keoptimalan pembelajaran siswa, peneliti menggunakan aktivitas Poll 3 kali, Open Ended Question 2 kali, Fill in The Blanks 2 kali dan Time to Climb 1 kali. Berikut akan diuraikan penggunaan aplikasi Nearpod dalam pembelajaran bahasa Indonesia.

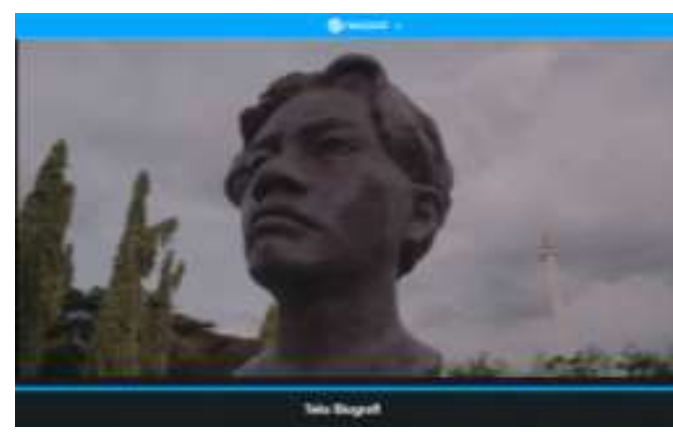

Pada materi pertama, peneliti menyajikan konten video yang terkoneksi langsung ke kanal Youtube Pembangunan Jaya dengan judul Video (JAYA 55) Maestro Indonesia - Chairil Anwar. Penggunaan video ini untuk membangkitkan motivasi dan ketertarikan siswa untuk belajar melalui audio visual yang menarik dan tentunya sesuai dengan materi yang akan dipelajari.

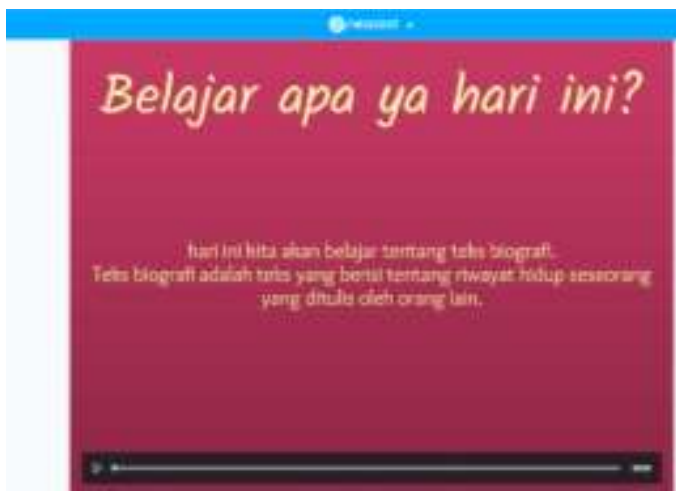

Selanjutnya, peneliti memulai pengajaran dengan memberikan informasi terkait materi yang akan dipelajari, yaitu teks biografi. Pada bagian ini, peneliti memanfaatkan konten slide yang dapat didesain langsung secar mandiri dalam aplikasi Nearpod. Menariknya, slide tersebut dapat ditambahi, dengan gambar dan audio seperti yang digunakan oleh peneliti.

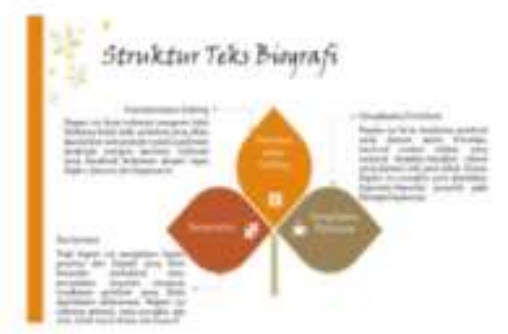

Peneliti juga menggunakan konten slide show untuk menampilkan salindia yang telah dibuat pada aplikasi bawaan laptop. Dengan demikian, konten slide dan slide show memiliki perbedaan. Sebagaimana pada gambaar di atas, peneliti menggunakan konten slide show untuk menampilkan materi strukturstruktur teks biografi, yang terdiri atas 
orientasi, rangkaian peristiwa, dan reorientasi.

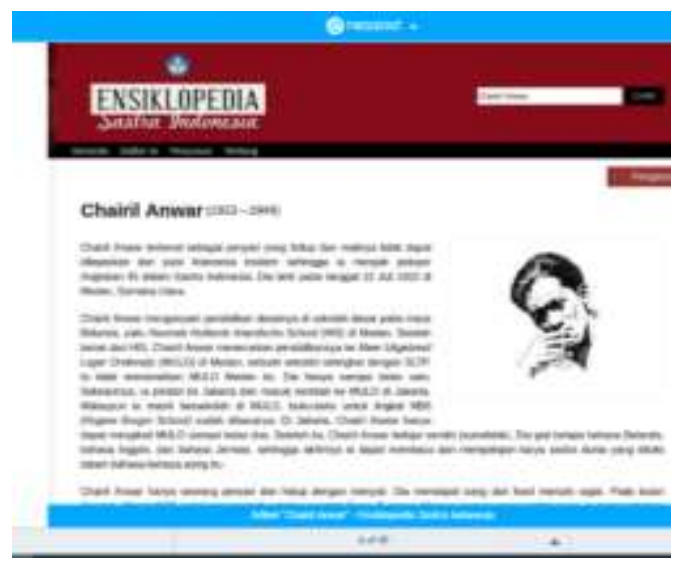

Materi teks biografi, memiliki beberapa kegiatan belajar. Kegiatan belajar 1 adalah membaca teks biografi. Untuk melakukan kegiatan tersebut, peneliti menggunakan konten Web Content yang ada dalam aplikasi Nearpod. Web Content ini langsung terhubung dengan website ensiklopedia sastra yang dikelola oleh kemendikbud, sebagai sumber terpercaya untuk menampilkan teks biografi Chairil Anwar.

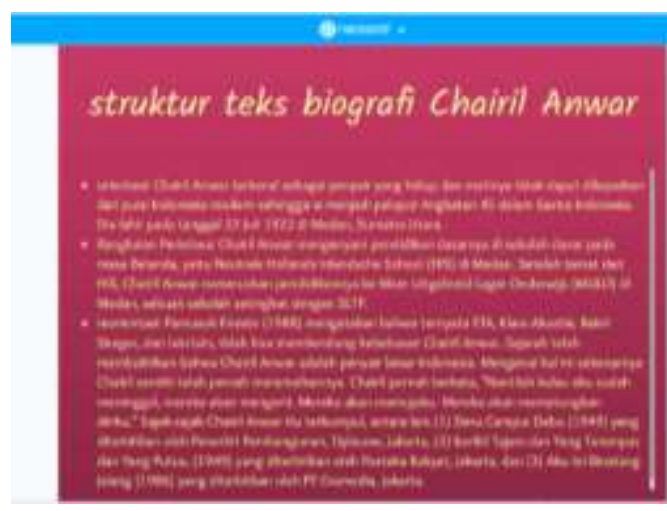

Peneliti kembali menggunakan slide show untuk memberikan kategorisasi biografi chairil anwar kepada struktur teks biografinya. Salah satu bagian kegiatan belajar 1, ialah praktik memahami struktur teks dari biografi. Menurut peneliti, penggunaan slide show sangat cocok untuk memberikan pemahaman tersebut.
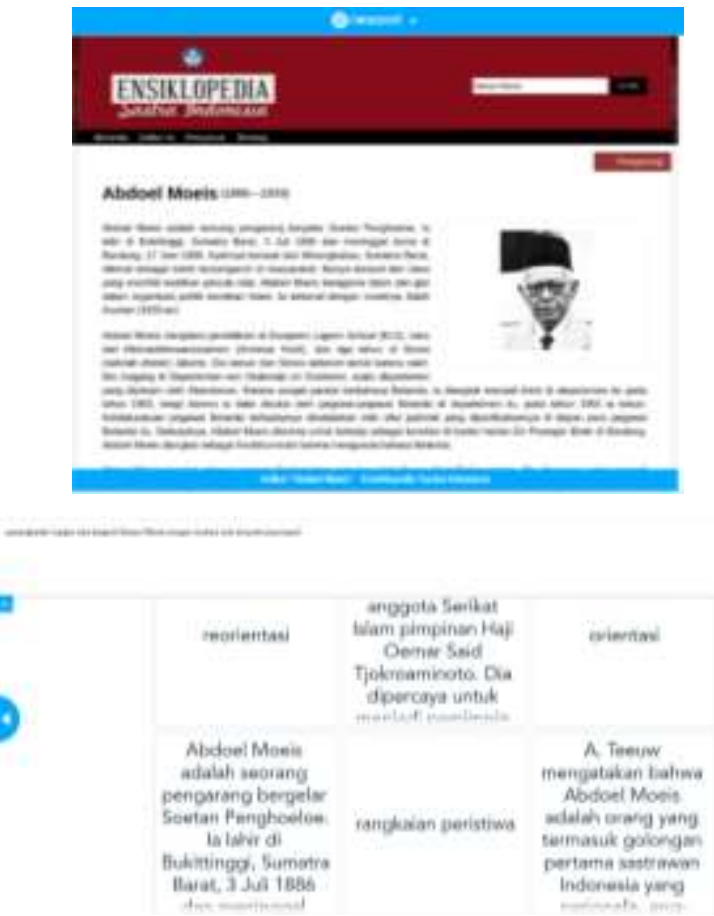

Kegiatan belajar 2 dalam materi teks biografi, ialah penyusunan teks biografi yang masuk ke dalam aspek penalaran. Untuk melakukan praktik penyusunan teks, peneliti terlebih dahulu menyajikan biografi Abdoel Moeis dengan memanfaatkan Web Content pada aplikasi Nearpod. Setelah itu, peneliti menggunakan matching pairs untuk memberikan susunan acak terkait orientasi, rangkaian peristiwa dan reorientasi Abdoel Moeis. Setelah para siswa selesai membaca dan memahami struktur teks biografi Abdoel Moeis, para siswa di persilakan untuk menyusun atau 
BAHTERA INDONESIA:

ISSN 2541-3252

Jurnal Penelitian Pendidikan Bahasa dan Sastra Indonesia

Vol. 6, No. 2 Sep. 2021

mencocokan penggalan teks dengan struktur teks biografi yang tepat. Secara praktis, Nearpod langsung memberikan hasil jawaban dari para siswa, sebagai berikut.

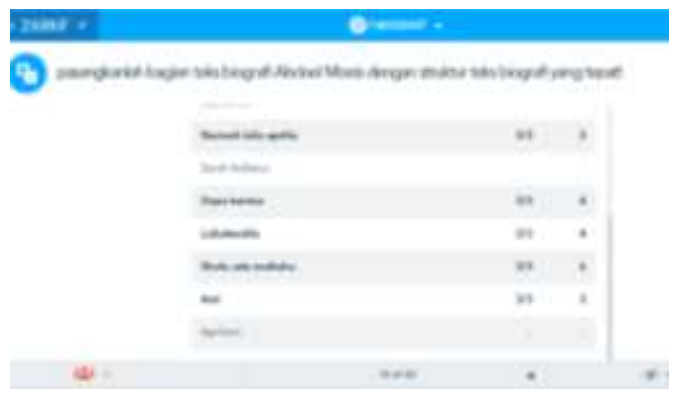

Kegiatan belajar 1 dan 2 telah selesai dilakukan. Tahap berikutnya peneliti melakukan evaluasi pembelajaran untuk mengamati dan melihat capaian belajar siswa atas pembelajaran yang baru saja dilakukan.

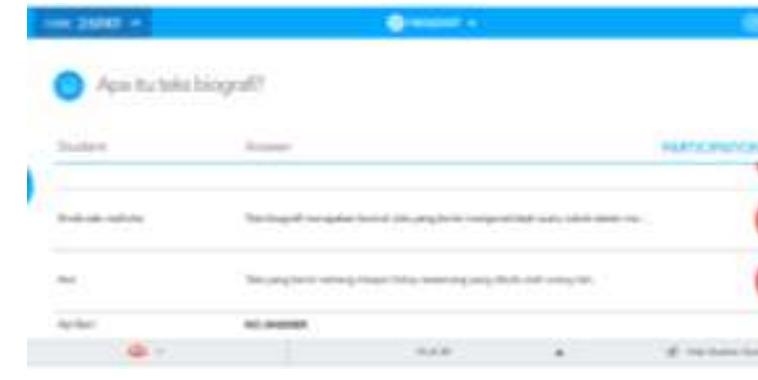

$$
\text { Evaluasi pertama, peneliti }
$$
menggunakan aktivitas Open Ended Question. Pada aktivitas ini, penelliti memberikan satu pertanyaan yang harus dijawab oleh para siswa dengan jawaban tertulis. Pertanyaan yang diberikan ialah terkait pengertian dari teks biografi, dan didapatkan hasil beberapa siswa menjawab dengan tepat.
Selanjutnya, peneliti menggunakan permainan edukasi time to climb yang terdapat dalam aplikasi Nearpod. Time to Climb ini semacam kuis yang diadakan secara bersamaan untuk para peserta dan terdapat ranking skor mulai dari yang teratas hingga terbawah. Time to climb sangat menarik digunakan karena memiliki tampilan layaknya games atau permainan.
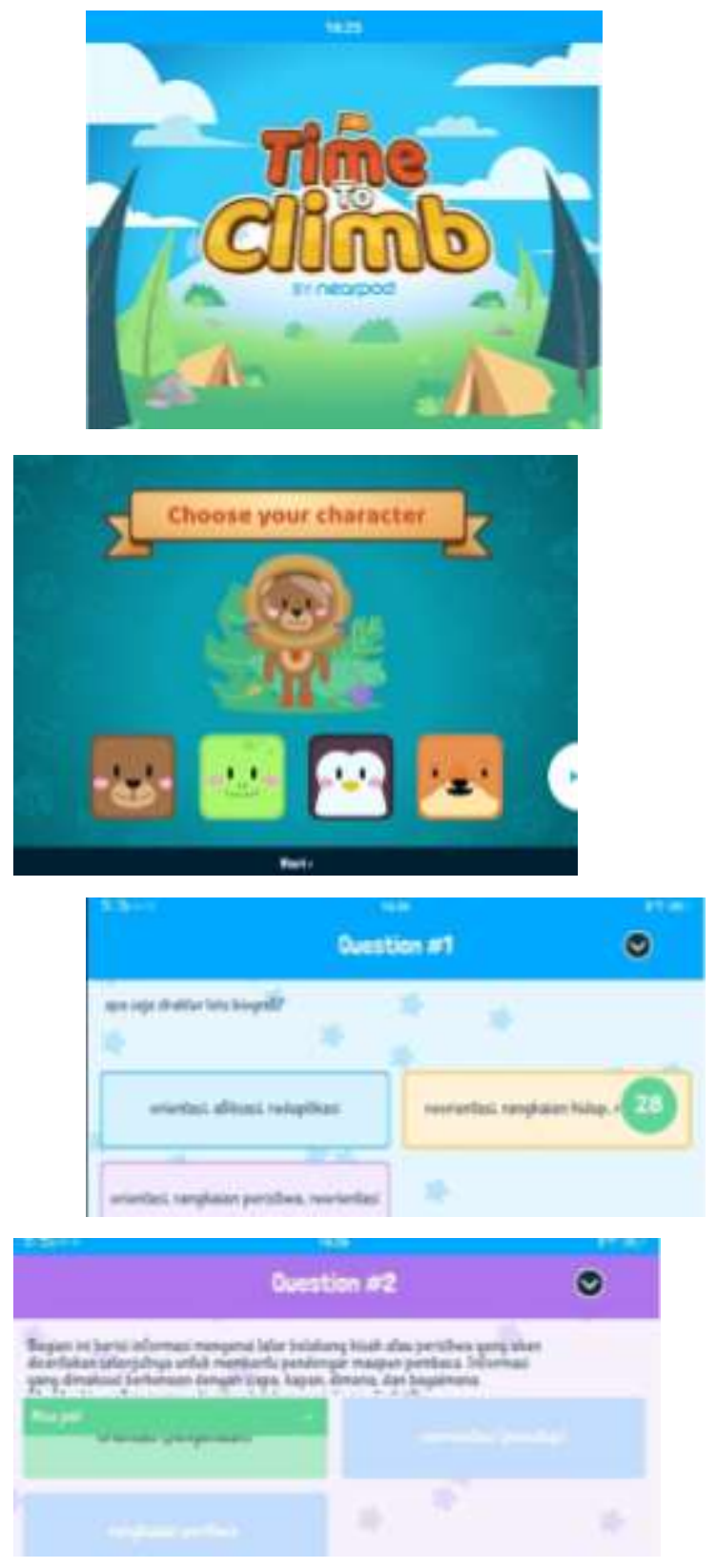


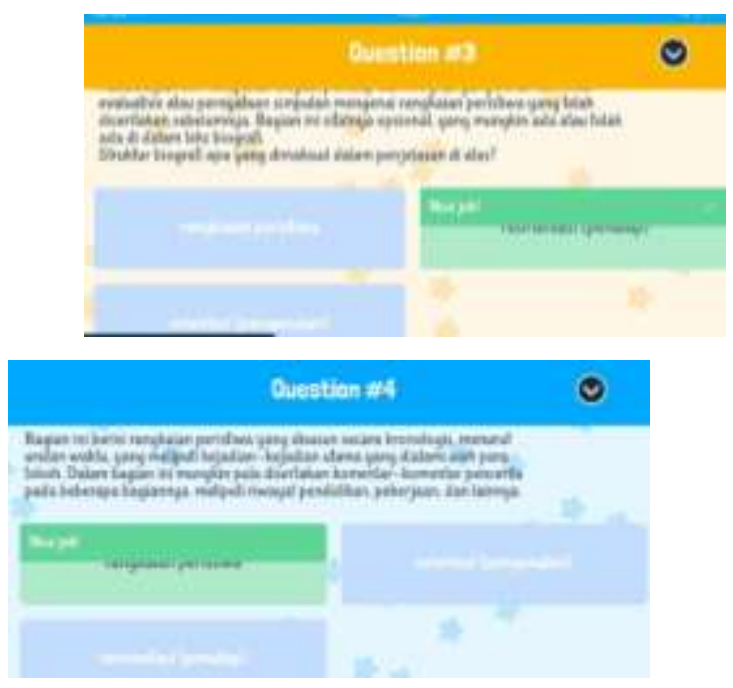

Peneliti mengajukan empat pertanyaan tentang struktur teks biografi, meliputi orientasi, rangkaian peristiwa, dan reorientasi. Berikut adalah hasil skor 5 teratas time to climb pada penelitian ini.

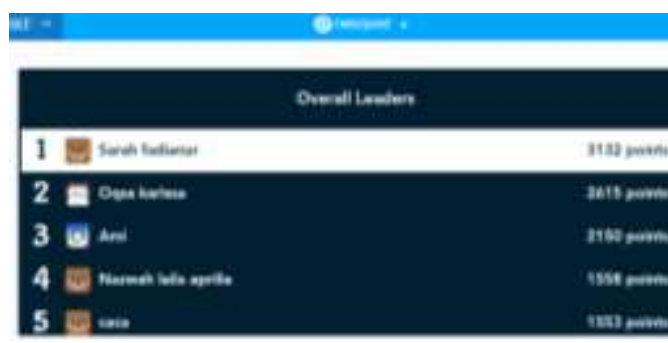

Evaluasi ketiga untuk pembelajaran yaitu terkait dengan pemahaman teks biografi Chairil Anwar dan Abdoel Moeis yang dilakukan dengan aktivitas fill in the blank sebagai berikut.

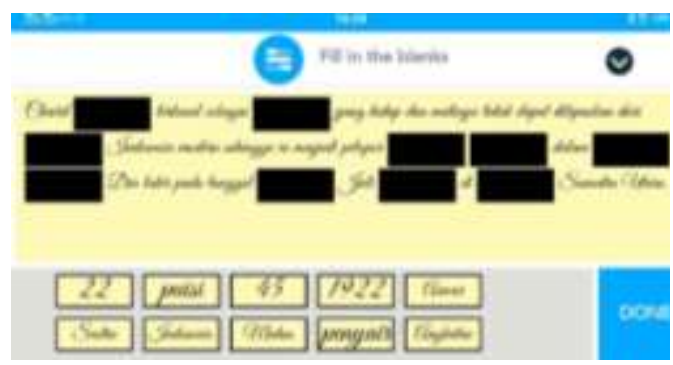

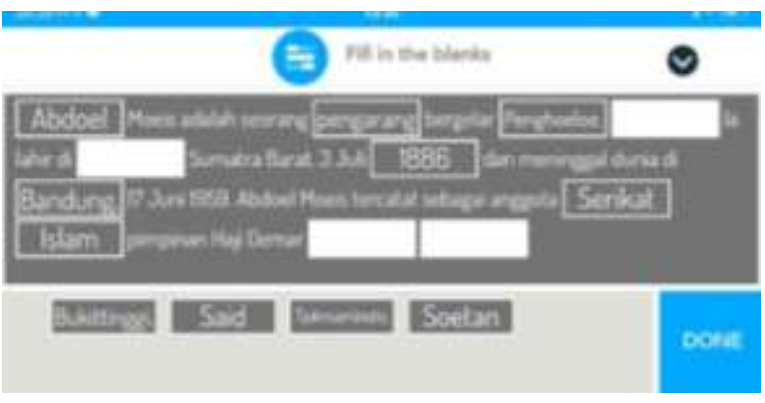

Tahap selanjutnya peneliti melakukan poll untuk melihat penilaian dan sebagai evaluasi penggunaan aplikasi ini, sebagai berikut.

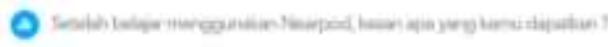
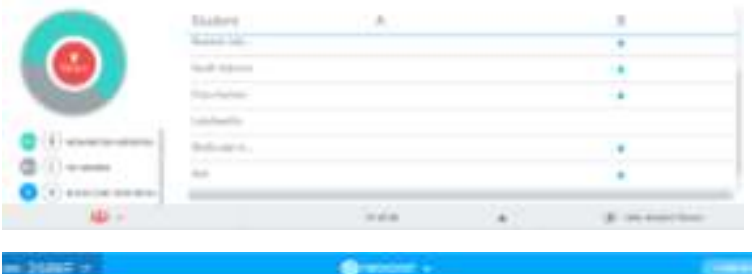

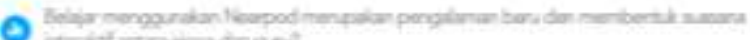

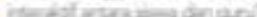

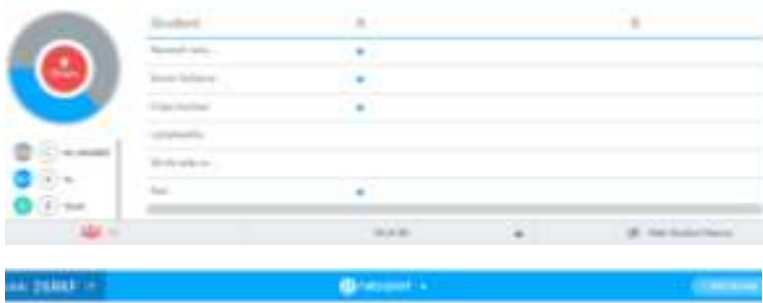

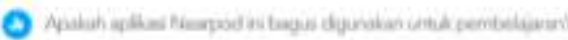

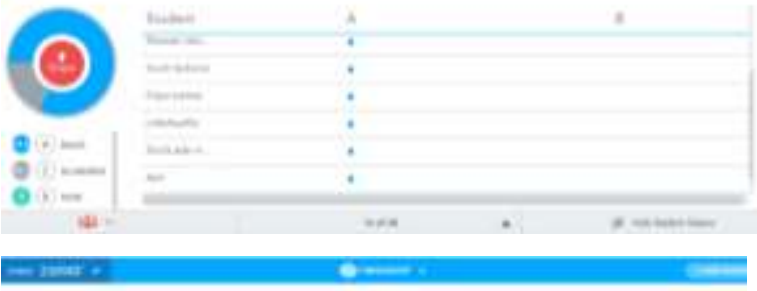

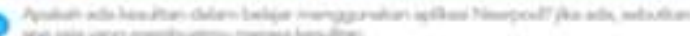

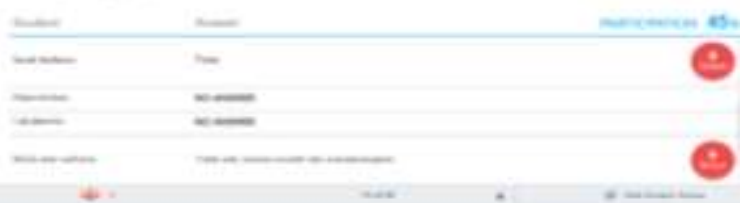




\section{Kelebihan dan Kelemahan Aplikasi} Nearpod dalam Pembelajaran

Kelebihan aplikasi Nearpod, yaitu (1) aplikasi ini sangat bagus untuk menciptakan pembelajaran jarak jauh secara interaktif; Nearpod memiliki banyak fitur, konten, aktivitas yang sangat kreatif, inovatif, dan edukatif; (3) Nearpod dapat diakses melalui telepon seluler sehingga praktis digunakan dan terbatas ruang dan waktu; (4) Nearpod memiliki fitur report untuk melihat rekam jejak pembelajaran yang berlangsung; (5) bida di akses secara gratis.

Sementara

kekurangan

aplikasi ini, yaitu

(1) penggunaan aplikasi Nearpod harus menggunakan data internet yang agak boros; (2) Harus didukung sinyal yang kuat, sehingga kurang efektif apabila diterapkan didaerah yang sinyalnya tidak mendukung dan tidak menjangkau penggunaan di pedesaan;

(3) Belum memiliki deteksi bahasa global, masih terbatas pada bahasa Inggris, sehingga sedikit menghambat bagi orang yang belum menguasai bahasa Inggris; (4) guru hanya bisa membuat modul pembelajaran melalui komputer.

\section{SIMPULAN}

Berdasarkan hasil dan pembahasan yang telah diuraikan di atas, diperoleh simpulan bahwa penggunaan aplikasi Nearpod dapat digunakan dalam pembelajaran jarak jauh. Penggunaan aplikasi Nearpod sangat dianjurkan kepada para guru karena memiliki banyak fitur inovatif dan edukatif untuk menciptakan pembelajaran yang interaktif, dapat diakses secara gratis, dan mudah diakses menggunakan selepon seluler oleh para siswa. Aplikasi Nearpod dapat mengoptimalkan pembelajaran Bahasa Indonesia, contohnya pada materi teks biografi. Pembelajaran bahasa Indonesia terkait teks biografi, dapat menggunakan konten aplikasi Nearpod, seperti Video, Web Conten, Slide dan Slide Show untuk penyampaian materi. Nearpod juga sangat paktis digunakan untuk mengevaluasi pembelajaran bahasa Indonesia teks biografi melalui aktivitas Matching Pairs, Open Ended Question, Time To Climb, Fill In the Blank, dan Poll.

\section{DAFTAR PUSTAKA}

Amerudin. Deskripsi Kesulitan Belajar dan Faktor Penyebabnya Pada Materi Fungi di SMA Islam Bawari Pontianak dan Upaya Perbaikannya. http://jurnal.untan.ac.id/index.php/jpdp b/article/download/3265/pdf.

Angkowo, Robertus., \& A. Kosasih. (2007). Optimalisasi Media Pembelajaran. Jakarta: PT Grasindo. 
Hamdanah \& Iqbal Hasanuddin. (2019). Media Pembelajaran Berbasis ICT: Pengaruh Penggunaan Media Pembelajaran Berbasis ICT Terhadap Hasil Belajar Mahasiswa. Parepare: IAI Parepare NusantarasPress.

Hanna. (2014). Pembelajaran Bahasa Indonesia Mau dibawa ke Mana?. Bahtera: Jurnal Pendidikan Bahasa dan Sastra.

https://media.neliti.com/media/publicat ions/327140-pembelajaran-bahasaindonesia-mau-dibawa-17d9b266.pdf.

Menteri Pendidikan dan Kebudayaan Republik Indonesia. Surat Surat Edaran Menteri Pendidikan dan Kebudayaan Republik Indonesia Nomor 4 Tahun 2020 tentang pelaksanaan kebijakan pendidikan dalam masa darurat penyebaran Coronavirus Disease (Covid-19). http://pgdikmen.kemdikbud.go.id/readnews/surat-edaran-mendikbud-nomor4-tahun-2020.

Sub Direktorat Statistik Komunikasi dan Teknologi Informasi. (2018). Statistik Telekomunikasi Indonesia. Jakarta:Badan Pusat Statistik.

Sugiyono. (2017). Metode Penelitian Kuantitatif, kualitatif dan $R \& D$. Bandung: Alfabeta.

Suryani, Nunuk. (2018). Media Pembelajaran Inovatif dan Pengembangannya. Bandung: PT. Remaja Rosdakarya. 